\title{
Posouzení funkčních objemů vodního díla Vír I na aktualizovaná vstupní data
}

\section{DANIEL MARTON, MILOŠ STARÝ}

\author{
Klíčová slova: funkční objem - nádrž - Vír I - zásobní funkce nádrže - ochranná funkce nádrže
}

\section{SOUHRN}

Cílem přispěvku je prednést výsledky studie, která měla za úkol posouzení účinnosti funkčních objemů nádrže Vír I na aktualizovaná vstupní data. Studie byla zaměřena na přepočet zásobního objemu, zabezpečenosti nalepšeného odtoku vody z nádrže a na posouzení ochranného objemu nádrže. Řešení zásobního objemu nádrže bylo provedeno pomocí reálných průtokových řad maximální dostupné délky měření a umělých průtokových řad. Přepočet ochranné funkce nádrže byl proveden pro teoretické povodňové vlny odvozené klasickou metodou a pomocí metody podmíněné pravděpodobnosti. Zadání vycházelo z požadavku aktualizace výpočtu uvedených veličin s ohledem na prodloužení délky měřených vstupních hydrologických podkladů, zejména pak s prìhlédnutím na sucho z roku 2015 a extrémní povodně posledních let.

\section{ÚVOD}

Poslední roky ukazují, že problém sucha se výrazně týká i některých regionů České republiky. V minulosti se hojně řešila problematika povodní a protipovodňové ochrany. Opačný extrém byl v pozadí. Dnes je však sucho stejně vážným tématem stejně jako v minulosti povodně. Poslední roky patří mezi nejteplejší v celé historii meteorologických pozorování. Na mnoha místech ČR byly pozorovány výrazné poklesy hladiny vodních tokủ. Na významných tocích se opětovně objevily hladové kameny, jedny z nejstarších informátorů o suchých obdobích $v$ českých zemích. Zásoby podzemních vod byly a stále jsou pod dlouhodobými normály. Některé vodní nádrže musely kvůli problémům $s$ nedostatkem vody přistoupit $\mathrm{k}$ mimořádným manipulacím. Nezapomínejme však, že možnost povodňového nebezpečí je stále prítomná, a je jí třeba věnovat pozornost. Proto úlohy spojené s přehodnocením funkčních objemů nádrží z pohledu aktuálních hydrologických problémů jsou vysoce aktuální. Počítá s ním i vládní dokument Strategie přizpůsobení se změně klimatu v podmínkách ČR [1], který si problematiku posouzení funkčních objemů stávajících nádrží vytyčil jako jeden z mnoha cílů adaptačních opatření v boji proti změně klimatu.

Předmětem př́spěvku je prezentace výsledků studie, která měla za úkol přepočet účinností funkčních objemů nádrže Vír I. Výpočty byly zaměřeny především na výpočet nalepšeného odtoku vody z nádrže ze stávajícího zásobního objemu nádrže při zadané zabezpečenosti odtoku a na posouzení ochranného účinku nádrže. Zadání vychází z požadavku podniku Povodí Moravy, s. p., na aktualizaci výpočtů uvedených veličin s ohledem na prodloužení délky měěných vstupních hydrologických podkladů. Přesněji aktualizaci řady průměrných měsíčních průtoků, tak aby zahrnovala suché epizody z devadesátých let minulého století, z roku 2014 a predevším z roku 2015.
Dále aktualizaci hydrogramů povodní, ve kterých jsou zahrnuty nedávné extrémní povodňové události z roku 1997 a následujících let. Hydrologické podklady poskytl ČHMú, pobočka Brno.

\section{METODIKA}

\section{Vodohospodářské řešení zásobní funkce nádrže}

Výpočet zásobní funkce nádrže byl proveden pomocí programu UNCERESERVOIR [2]. Základem programu je simulační model chování nádrže, který popsal Starý, viz [3]. Algoritmus softwaru vychází z upravené základní rovnice nádrže $\checkmark$ součtovém tvaru, která je omezena podmínkou typu nerovnosti. Výpočet zabezpečenosti je proveden podle klasického vztahu Čegodajeva, viz [3], a normy ČSN 752405 [4], kdy je stanovena zabezpečenost podle trvání $P_{T}$ a množství nedodané vody $P_{D}$. Simulační model nádrže do výpočtů zahrnuje i ztráty vody z nádrže. Ztráty jsou uvedeny ve formě ztráty vody výparem z vodní hladiny a průsakem tělesa hráze. Ztráty jsou řešeny iterační metodou.

Vzhledem k významu vodního díla Vír I bylo provedeno i řešení pomocí umělých průtokových řad. K sestrojení umělých průtokových řad byl použit program LRM soft [5]. Algoritmus generátoru vychází ze standardního postupu generování umělých průtokových řad, který popsal Starý, viz [6]. Řídicí rovnice generátoru včetně principu jejich použití dále popsal Kos, viz [7].

\section{Vodohospodářské řešení ochranné funkce nádrže}

Proces transformace povodňové vIny nádrží byl simulován pomocí programu HYDROG [8]. Pro transformaci povodně (řešení základní rovnice nádrže v diferenciálním tvaru) je v programu použita explicitní diferenční metoda Runge-Kutta 4. rádu. Metoda umožňuje provádět diskrétní bodovou simulaci spojitého procesu.

\section{PRAKTICKÁ APLIKACE}

Základní hydrologické údaje o povodí nad nádrží. Nádrž je vybudována v povodí řeky Svratky a řeka Svratka je také hlavním prítokem vody do nádrže. Plocha povodí nad nádrží je přibližně 410,35 km². Průměrný dlouhodobý prítok vody do nádrže je $\mathrm{Q}_{\mathrm{a}}=3,607 \mathrm{~m}^{3} \cdot \mathrm{s}^{-1}$. Ekologický průtok tvořící hranici sucha je $\mathrm{Q}_{355}$ a odpovídá průtoku $0,48 \mathrm{~m}^{3} \cdot \mathrm{s}^{-1}$. Časová řada průměrných měsičních průtoků byla použita z měření ve vodoměrném profilu Dalečín, který se nachází bezprostředně nad nádrží. Prưměrná hodnota měřeného výparu z vodní hladiny odpovídá hodnotě $\mathrm{E}_{\mathrm{a}}=613 \mathrm{~mm} / \mathrm{rok}$. 


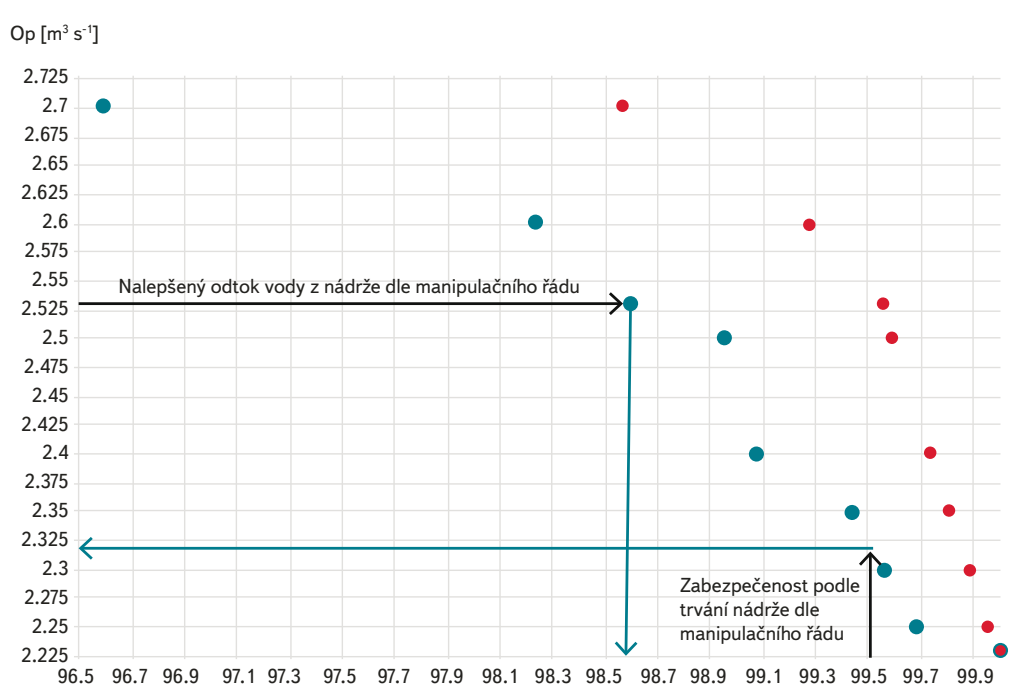

PT PD

Obr. 1. Vztah mezi zabezpečeností odtoku vody z nádrže a hodnotou nalepšeného odtoku vody z nádrže - reálná průtoková řada

Fig. 1. Relation between reliability of reservoir outflow and total water outflow historical flow series

Těleso hráze nádrže Vír I je betonové tížné složené z 26 bloků. Délka hráze v koruně hráze je $390 \mathrm{~m}$. Celková výška hráze je 67,3 m. Šířka hráze v koruně je 9 m. Dno údolí u hráze je 404,24 m n. m. a kóta koruny hráze je 470,45 m n. m. Výpustná a odběrná zařízení jsou tvořena 2x spodní výpustí DN $1800 \mathrm{~mm}$ a jednou asanační výpustí DN 200 mm. Bezpečnostní přeliv je konstrukce korunové nehrazené o celkové délce $60,5 \mathrm{~m}$ a maximální kapacitě $180,5 \mathrm{~m}^{3} \cdot \mathrm{s}^{-1}$ při hladině 468,45 m n. m. Nádrž slouží také k elektrárenským účelům. Na pravé straně hráze je vybudována vodní elektrárna s dvěma turbínami o hltnosti $2 \times 12 \mathrm{~m}^{3} \cdot \mathrm{s}^{-1}$. Minimální požadovaný odtok vody z nádrže je $\mathrm{MQ}=0,530 \mathrm{~m}^{3} \cdot \mathrm{s}^{-1}$. Neškodný průtok je $Q_{N E}=55 \mathrm{~m}^{3} \cdot \mathrm{s}^{-1}$. Celkový objem nádrže je $\mathrm{V}=56,193 \mathrm{mil}$. $\mathrm{m}^{3}$. Prostor stálého nadržení je $V_{s}=3,800$ mil. m³. Zásobní objem nádrže je $V_{z}=44,056$ mil. m³. Ochranný objem nádrže je $V_{R}=8,337$ mil. $\mathrm{m}^{3}$. Celkový rovnoměrný odběr vody z nádrže Vír I je stanoven podle manipulačního rádu [9] na hodnoty nalepšeného odtoku $\mathrm{O}_{p}=2,53 \mathrm{~m}^{3} \cdot \mathrm{s}^{-1}$. Nalepšený odtok je rozdělen na dílčí odběry a minimální odtok do toku MQ. Odběr z nádrže pro oblast Ždár nad Sázavou je $Q_{\text {Ż́AR }}=0,2 \mathrm{~m}^{3} \cdot \mathrm{s}^{-1}$. Odběr pro Vírský oblastní vodovod včetně odběru vody pro Brno a jeho okolí je $\mathrm{Q}_{\mathrm{vov}}=1,8 \mathrm{~m}^{3} \cdot \mathrm{s}^{-1}$. Všechny uvedené parametry vychází z platného manipulačního rádu k vodnímu dílu [9].

\section{Vodohospodářské řešení zásobní funkce nádrže}

Výpočet byl proveden pro vyhodnocení zabezpečenosti odtoku vody z nádrže $P_{T}$ a $P_{D}$. Vstupní hodnoty pro výpočet zásobního objemu nádrže tvořila časová rada prưměrných měsíčních průtoků měřených ve vodoměrném profilu Dalečín. Délka hydrologické řady je 65 let za období měření 1950 až 2015. Vzhledem k účelu nádrže byla ve výpočtech použita i data z generátorů umělých průtokových řad. Pro tyto účely byl vybrán a použit lineární regresní model s délkou regresní závislosti 4 a celkovou délkou generované umělé průtokové raady 10000 let. Zásobní objem nádrže byl počítán s uvažováním ztrát vody z nádrže. Úloha byla řešena pro hodnotu zásobního objemu nádrže daného v [9]. Kdy hodnota $O_{p}$ byla postupně zvyšována a pro volené $O_{p}$ byly vždy dopočítávány hodnoty zabezpečeností $P_{T}$ a $P_{D}$. Výsledky byly porovnány ze dvou pohledů. První byla změna $P_{T}$ při uvažování $O_{p}=2,53 \mathrm{~m}^{3} \cdot \mathrm{s}^{-1}$ daného $v$ [9]. Druhý pohled byl ve změně $O_{p}$ při uvažování zabezpečenosti $P_{T}=99,5 \%$ dané v [4] a [9].
Op $\left[\mathrm{m}^{3} \mathrm{~s}^{-1}\right]$

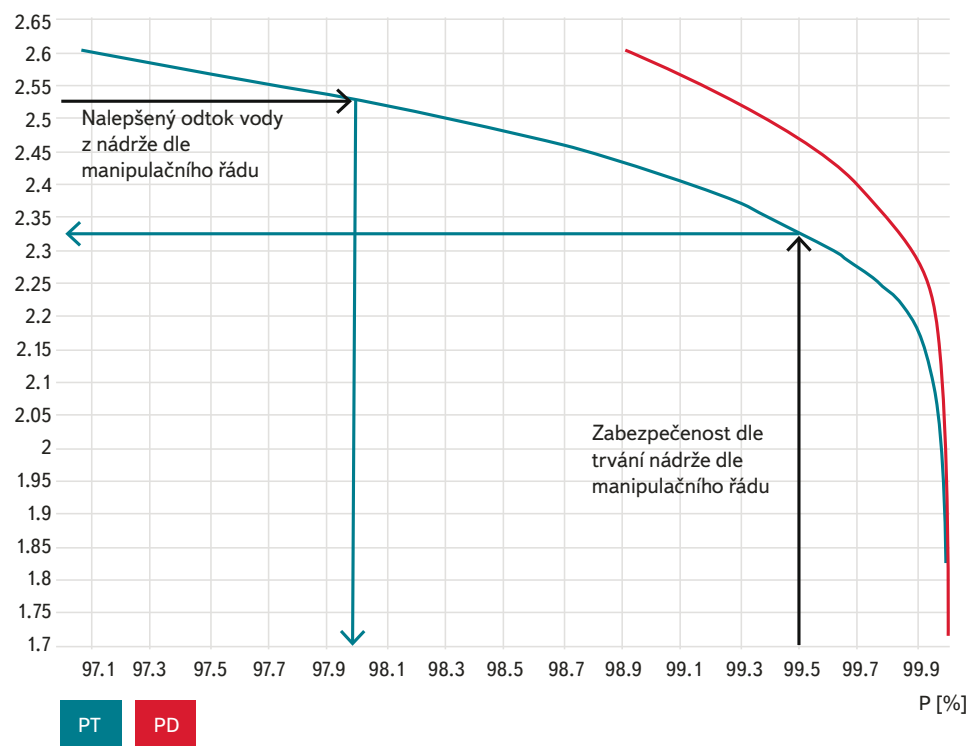

Obr. 2. Vztah mezi zabezpečeností odtoku vody z nádrže a hodnotou nalepšeného odtoku vody z nádrže - umělá průtoková řada

Fig. 2. Relation between reliability of reservoir outflow and total water outflow artificial flow series

\section{Vodohospodářské řešení ochranné funkce nádrže}

Cílem řešení bylo posoudit, zda a jakým způsobem nádrž převede aktualizované povodňové viny $\mathrm{PV}_{100^{\prime}}$ návrhovou $\mathrm{PV}_{1000}$ a kontrolní $P V_{10000}$. Přitom povodňové vIny byly aktualizované ČHMÚ v roce 2008 [10]. Podklady, ze kterých byly povodňové vlny zkonstruované, zahrnovaly i extrémní historické povodně z posledních let z konce minulého století a ze začátku současného století.

Povodně byly odvozeny jednak klasickým způsobem a jednak pomocí podmíněných pravděpodobností s 30\% podmíněnou pravděpodobností překročení objemu povodňové viny, v tabulkách uvedeno pod zkratkou PP. Za simulovaného průchodu povodně byl sledován transformační účinek nádrže a byl odečten vždy kulminační odtok vody z nádrže $\mathrm{O}_{\text {max }^{\prime}}$ který byl porovnán s hodnotou neškodného odtoku vody z nádrže $\mathrm{O}_{\mathrm{NE}}=55 \mathrm{~m}^{3} \cdot \mathrm{s}^{-1}$. Dále byla odečtena kóta maximální hladiny v nádrži $H_{\max { }^{\prime}}$ která byla následně porovnána s mezní bezpečnou hladinou MBH stanovenou pro nádrž Vír I na kótě 470,45 m n. m. Při výpočtech byly testovány dva vybrané způsoby řizení odtoku vody z nádrže. První způsob neumožňuje provést pred nástupem povodně povyprázdnění zásobního objemu nádrže, doporučení podle [11]. Uvedená varianta je v dalším textu a obrázcích označena jako varianta bez predpouštění. Druhý způsob se liší od prvního způsobu rízení tím, že umožňuje operativně povyprázdnit zásobní objem nádrže před nástupem povodně, tzv. varianta s předpouštěním. Pro jednoduchost je z nádrže hned vypouštěn odtok roven neškodnému odtoku. Jedná se tedy o agresivní způsob řízení odtoku vody z nádrže ve vztahu ke korytu toku pod nádrží. Oba způsoby řizení jsou pro posouzení mezní a určují interval, ve kterém je možno hledat i jiné způsoby řizení odtoku vody z nádrže za průchodu návrhové povodňové vlny. 


\section{VÝSLEDKY A DISKUSE}

\section{Vodohospodářské řešení zásobní funkce nádrže}

Obrázek 1 a 2 ukazují výsledky výpočtů zabezpečenosti $P_{T}$ a $P_{D}$. Opakovaně byla měněna hodnota nalepšeného odtoku a stanovena zabezpečenost až byly sestaveny závislosti $O_{p}$ na $P_{T}$ a $P_{D}$. Obrázek 1 popisuje závislost odtoku vody z nádrže a zabezpečenosti stanovenou v reálné průtokové řadě. Obrázek 2 pak popisuje stejnou závislost, ale vstupem do výpočtu je umělá průtoková raada. Odečty v grafech ukazují výsledky porovnání s hodnotami uvedenými v manipulačním řádu k vodnímu dílu Vír I [9].

Jak bylo uvedeno výše. Podle manipulačního rádu zásobnímu objemu nádrže $44056000 \mathrm{~m}^{3}$ odpovídá nalepšený odtok $\mathrm{O}_{p}=2,53 \mathrm{~m}^{3} \cdot \mathrm{s}^{-1}$ při zabezpečenosti podle trvání $P_{T}=99,5 \%$.

Při zachování nalepšeného odtoku $\mathrm{O}_{p}=2,53 \mathrm{~m}^{3} \cdot \mathrm{s}^{-1}$ a zásobního objemu $44056000 \mathrm{~m}^{3}$ je zabezpečenost $v$ reálné průtokové řadě $P_{T}=98,59 \%$. Zabezpečenost nevyhoví a rozdíl činí 0,91\%. V umělé raadě je zabezpečenost $P_{T}=97,99 \%$. Zabezpečenost opět nevyhoví a rozdíl činí 1,51 \%.

Při zachování zabezpečenosti $P_{T}=99,5 \%$ a zásobního objemu $44056000 \mathrm{~m}^{3}$ je nalepšený odtok vody z nádrže $O_{\mathrm{p}}=2,32 \mathrm{~m}^{3} \cdot \mathrm{s}^{-1} \mathrm{v}$ reálné průtokové řadě. Nalepšení odtoku vody z nádrže nevyhoví a rozdíl činí $0,21 \mathrm{~m}^{3} \cdot \mathrm{s}^{-1}$. V umělé průtokové řadě vychází nalepšení odtoku vody z nádrže $\mathrm{O}_{\mathrm{p}}=2,32 \mathrm{~m}^{3} \cdot \mathrm{s}^{-1}$ a rozdíl opět činí $0,21 \mathrm{~m}^{3} \cdot \mathrm{s}^{-1}$.

\section{Vodohospodářské řešení ochranné funkce nádrže}

Souhrnné zhodnocení dosažených efektů pro oba mezní způsoby řízení odtoku vody z nádrže za průchodu povodní $\mathrm{PV}_{100^{\prime}} \mathrm{PV}_{1000}$ a $\mathrm{PV}_{10000}$ jsou uvedeny $\checkmark$ tabulce 1 a tabulce 2 .

Z uvedených tabulek plyne, že ve variantě bez předpouštění vody z nádrže byl pro všechny hydrogramy povodní neškodný odtok v korytě pod nádrží vždy prekročen. Pozitivní skutečností je, že maximální bezpečnostní hladina nebyla pro žádnou N-letost dosažena.

Ve variantě s předpouštěním vody z nádrže pro hydrogram $\mathrm{PV}_{100}$ a pro hydrogram PP PV 100 navržený pomocí podmíněných pravděpodobností byl neškodný odtok v korytě pod nádrží kulminačním odtokem dosažen. Pro všechny ostatní hydrogramy povodní s N-letostí 1000 a 10000 roků byl neškodný odtok v korytě pod nádrží kulminačním odtokem vždy překročen. Pozitivní skutečností opět je, že maximální bezpečnostní hladina nebyla pro žádnou N-letost dosažena.

Tabulka 1. Dosažené efekty prì transformaci - varianta bez predpouštění Table 1. Resulting transformation effects - alternative without emptying

$\begin{array}{llll} & \text { Menší } & & \text { Menší } \\ \mathbf{O}_{\max } & \text { nebo } & \mathbf{H}_{\max } & \text { než } \\ {\left[\mathrm{m}^{3} / \mathrm{s}\right]} & \text { rovno } & {[\mathrm{m} \mathrm{n} . \mathrm{m} .]} & \text { MBH? } \\ & \mathbf{O}_{\mathrm{NE}}{ }^{3} & & \end{array}$

\begin{tabular}{lllll}
\hline $\mathrm{PV}_{100}$ & 81,7 & $\mathrm{Ne}$ & 468,38 & Ano \\
\hline $\mathrm{PPPV}$ & 125,0 & $\mathrm{Ne}$ & 468,05 & Ano \\
\hline $\mathrm{PV}_{1000}$ & 235,4 & $\mathrm{Ne}$ & 468,52 & Ano \\
\hline $\mathrm{PPPV}_{1000}$ & 272,5 & $\mathrm{Ne}$ & 468,66 & Ano \\
\hline $\mathrm{PV}_{10000}$ & 369,0 & $\mathrm{Ne}$ & 469,03 & Ano \\
\hline $\mathrm{PP} \mathrm{PV}$ & 409,0 & $\mathrm{Ne}$ & 469,16 & Ano
\end{tabular}

\section{ZÁVĚR}

Podle provedených výpočtů je zřejmé, že nádrž Vír I, která je zařazena do třídy významnosti $A\left(P_{T} \geq 99,5 \%\right.$ ), má vzhledem k aktualizovaným datům téměř o 1 \% menší hodnoty zabezpečenosti podle trvání. Nižší je i nalepšený odtok vody z nádrže. Z výpočtů je zřejmý pokles nalepšeného odtoku o přibližně $0.21 \mathrm{~m}^{3} \cdot \mathrm{s}^{-1}$. Toto snížení pokrývá napríklad odběr vody pro Ždársko. Je tedy zřejmé, že kapacita zdroje vody pro zásobené oblasti Ždárska, Bystřicka, Brna a okolí je $\checkmark$ současnosti negativně nadhodnocena. Vzhledem k probíhajícím změnám klimatu je však možné očekávat další budoucí pokles př́toku vody do nádrže. Toto tvrzení je však nutné prokázat důkladnou analýzou vlivu změny klimatu na zásobní objem nádrže. Přitom upřednostnění odběrů vody z nádrže před odtokem vody do toku může mít při dlouhodobém držení průtoku vody v řece Svratce pod nádrží Vír I na nízkých hodnotách fatální důsledky. Mohou nastat problémy spojené $s$ jakostí vody a biologickou rovnováhou $v$ toku. Je tedy ž̌ejmé, že při výpadku zásobení Brna vodou z prameniště Březová, nemá Brno ekvivalentní náhradní zdroj.

Jak ukazují průběžné výsledky provedené analýzy, řešením je navýšení zásobního objemu v nádrži Vír. Protože to však není možné, logicky se nabízí hledat příslušný zásobní objem výše po toku, kde se nabízí vybudování nádrže $\checkmark$ dlouhodobě hájeném profilu Borovnice.

Ochranná funkce nádrže byla přepočitána z pohledu průchodu aktualizovaných povodňových vin. Dosažené výsledky uvedené v tabulkách ukazují, že i v této oblasti je její transformační schopnost nadhodnocena. Nádrž není schopna bez předpouštění udržet kulminační odtoky pod hodnotou neškodného odtoku. Předpouštění je však u nádrže Vír I možné, protože má trvalou obsluhu a je navázána na vodohospodářský dispečink. Ten získává operativní předpovědi př́toků z ČHMÚ, který je poskytuje. Navíc má i dostatečné technické vybavení. Spodní výpusti disponují dostatečnou kapacitou pro uvedenou činnost.

Uvedený způsob předpouštění je hodně agresivní a v některých případech testovaných kontrolních povodní vede pří dlouhých nábězích vzestupných větví povodní ke značnému vyprázdnění zásobního objemu nádrže. Zpracovatelé jej považují pouze jako mezní řešení. Způsoby rízení odtoku je třeba podrobně analyzovat a zjištěné skutečnosti promítnout do manipulačního řádu, který je třeba s ohledem na zjištěné skutečnosti neprodleně aktualizovat.

Tým zpracovatelů studie přistupoval k přehodnocení ochranné funkce nádrže s nadějí, že bude v dané oblasti její kapacita mírně předimenzovaná, že bude možno snižit retenční objem nádrže ve prospěch zásobní funkce a posílit její možnosti v oblasti zásobení vodou. Dosažené výsledky však ukázaly,

Tabulka 2. Dosažené efekty při transformaci - varianta s předpouštěním Table 2. Resulting transformation effects - alternative with emptying

\begin{tabular}{|c|c|c|c|c|}
\hline & $\begin{array}{l}\mathbf{O}_{\max } \\
{\left[\mathrm{m}^{3} / \mathrm{s}\right]}\end{array}$ & $\begin{array}{l}\text { Menší } \\
\text { nebo } \\
\text { rovno } \\
\mathrm{O}_{\mathrm{NE}} ?\end{array}$ & $\begin{array}{l}\mathbf{H}_{\max } \\
{[\mathrm{m} \mathrm{n.m.]}}\end{array}$ & $\begin{array}{l}\text { Menši } \\
\text { než } \\
\text { MBH? }\end{array}$ \\
\hline$P V_{100}$ & 55,0 & Ano & 467,50 & Ano \\
\hline $\mathrm{PP} \mathrm{PV}_{100}$ & 55,0 & Ano & 456,40 & Ano \\
\hline$P V_{1000}$ & 195,0 & $\mathrm{Ne}$ & 468,30 & Ano \\
\hline$P P P_{1000}$ & 166,7 & $\mathrm{Ne}$ & 468,23 & Ano \\
\hline$P V_{10000}$ & 369,0 & $\mathrm{Ne}$ & 469,10 & Ano \\
\hline PP PV & 410,0 & $\mathrm{Ne}$ & 469,16 & Ano \\
\hline
\end{tabular}


že tato cesta není možná. Jako možné řešení se opět nabízí hledat další ochranný prostor výše po toku, využít hájený profil Svratka/Borovnice pro výstavbu nové nádrže. Důvod je velmi závažný. Nádrž Vír I je z pohledu zásobní i ochranné funkce vzhledem k aktuálním hydrologickým podkladům poddimenzovaná.

\section{Poděkování}

Tento př̀ispěvek je výsledkem specifického výzkumu FAST-J-17-4214 Nové pojetí ekonomického návrhu nádrže v podmínkách hlubokých nejistot s použitím multikriteriální optimalizace.

Příspěvek byl publikován ve sborníku konference Vodní nádrže 2017, ISBN 978-80-905368-5-2.

\section{Literatura}

[1] Strategie přizpuisobení se změně klimatu v podminkách ČR. Ministerstvo životního prostředí [online] 2015 [cit. 2017-06-18]. Dostupné z: http://www.mzp.cz

[2] MARTON, D., STARÝ, M. a MENŠ́́K, P. UNCERESERVOIR - Vodohospodářské rešenízásobní funkce nádrže. Dostupné z: http://uvhk.fce.vutbr.cz/software. php

[3] STARÝ, M. Nádrže a vodohospodářské soustavy (MODUL 01). Brno: VUT v Brně - Fakulta stavební, 2006.

[4] Česká technická norma ČSN 752405 Vodohospodářské řešeni vodnich nádrží, ICS 93.160; 13.060.10 Praha: Český normalizační institut, 2004.

[5] MARTON, D. a STARÝ, M. LRMsoft-generátorumělých měsíčních průtoků. Dostupnéz: http://uvhk.fce. vutbr.cz/software. php

[6] STARÝ, M. Hydrologie (MODUL 01). Brno: VUT v Brně - Fakulta stavební, 2005

[7] KOS, Z. Lineárníregresní model a jeho aplikace v hydrologii. Vodní toky v Praze. Praha, 1969.

[8] STARÝ, M. HYDROG - Software pro simulaci a operativni řizení odtoku vody z povodi, 1991-2017, Brno.

[9] Manipulační rád pro vodní dílo Vír I na rece Svratce. Brno: Povodí Moravy, s. p., 2011

[10] JURÁNEK, L. Hydrologická studie pro VD VÍR I, Odvození teoretických povodňových vln různými statistickými metodami. Brno: ČHMÚ, 2008.

[11] Česká technická norma ČSN752935 Posuzováníbezpečnosti vodních děl prí povodních, ICS 13.200; 93.160. Praha: Český normalizační institut, 2014.

\section{Autoři}

Ing. Daniel Marton, Ph.D.

凶marton.d@fce.vutbr.cz

prof. Ing. Miloš Starý, CSc.

凶stary.m@fce.vutbr.cz

Vysoké učení technické v Brně, Fakulta stavební,

Ústav vodního hospodářství krajiny

Příspěvek prošel lektorským řízením.

\section{STORAGE CAPACITY ASSESSMENT OF WATER} RESERVOIR ON CURRENT HYDROLOGIC DATA

\section{MARTON, D.; STARY, M.}

Brno University of Technology, Faculty of Civil Engineering, Institute of Landscape Water Management

Keywords: reservoir volume - reservoir - Vír I -

storage capacity - flood capacity

The aim of this paper is to present results of study, which was aimed to evaluate the efficiency of reservoir capacities for updated input data. The study has focused on review of storage capacity, reliability of total reservoir outflow and analysis of flood protection capacity. Storage capacity was made using historical flow time series of maximum length of historical measurements as well as using artificial flow time series. The review of the flood protection capacity was made for the theoretical flood hydrographs derived by the classical method as well as the Method of Conditional Probability. The given objectives is based on the requirement to update the calculations of above mentioned quantities with point of view to extending of length of measured input hydrological data, especially taking into account the 2015 drought and the extreme flood in recent years. 